\title{
Coğrafya-Din İlişkisi; Kentlileşme, Muhafazakârlık ve Mezhep Demografisi Bağlamında Doğu ve Batı Karşılaştırması
}

DOI: $10.26466 /$ opus.600344

\author{
Abdullah Aydın ${ }^{*}-$ Yusuf Okşar** \\ * Dr. Öğr. Üyesi Hatay Mustafa Kemal Üniversitesi İ̈BF, Uluslararası İlişkiler Bölümü, Hatay \\ E-Posta: aaydin@mku.edu.tr \\ ORCID: 0000-0002-1785-4999 \\ ** Dr. Öğr. Üy Hatay Mustafa Kemal Üni, İlahiyat Fakültesi, Temel İslam Bilimleri Bölümü Hatay \\ E-Posta: josephus1907@gmail.com \\ ORCID: 0000-0002-9060-3272
}

$\ddot{O} z$

Bu çalışmada kentleşme ve kentlileşme kavramları bağlamında Batı-Doğu arasındaki farklılıklar da ortaya konularak incelenmiştir. Ayrıca muhafazakârlığın ne şekilde tezahür ettiği ve mezhep algısının bu bağlamda nasıl bir süreç geçirdiği üzerinde durulmuştur. Bu bağlamda çalışmada geniş bir şekilde muhafazakârlık tanımı yapılarak, ardından kent muhafazakârlığı kavramı üzerinde durulmuştur. Bu amaçları gerçekleştirmek üzere çalışma yerli ve yabancı kaynaklardan elde edilen birincil ve ikincil verilerden faydalanarak hazırlanmıştır. Sonuç olarak şehirler ve medeniyetleri arasında karşılıklı bir ilişsinin söz konusu olduğu ve Müslüman muhafazakârlaşmasının değiş̧n kentlileşme olgusu ile yakından ilgisi olduğu görülmüştür. Batının kentlileşme olgusunu çok önceden tamamlamış olduğu ve buna paralel olarak muhafazakârlık tutumlarının farklı geliştiği tespit edilmiştir. Diğer taraftan gö̈ç, çarpık yapılaşma ve medeniyet olgusunun yozlaşması ile birlikte Müslümanların köy-kent ikileminde kaldığı ve bunun da bir bakıma gelenek-modernizm çatışmasını doğurduğu sonucuna ulaşılmıştır. Ayrıca toplumsal refleks, taklit (ailede hazır halde bulunan mezhebi kabulleniş), o coğrafyada bulunan âlimin etkisi ve fikirleriyle oluşan mezhep, göçler, tarihi süreçte ortaya çıkan bir takım krizler ve kırılmalar ve son tahlilde zikri geçen ifadelerde olduğu gibi mezhebi bir kimlik olarak benimsememe durumları genel şehir hayatı içerisindeki mezhep algısın ve tutumunu yakından ilgilendirmektedir.

Anahtar Kelimeler: Kentleşme, Muhafazakârlık, Modernizm, Doğu, Batı, Mezhep 


\title{
Relationship between Geography and Religion; Comparison of East and West in the Context of Urbanization, Conservatism and Denomination Demographics
}

\begin{abstract}
In this study, we focus on how the conservatism is manifested by revealing the differences between the urbanization and urbanization, and the differences between the East and the West. In this context, the concept of conservatism be broadly defined and then the concept of urban conservatism be emphasized. Finally, the aim of the study is to make a comparison and try to understand the historical change of the urbanization process of the Islamic world. In order to achieve this aim, the study be prepared by using primary and secondary data obtained from domestic and foreign sources. As a result, it is seen that there is a mutual relationship between cities and civilizations and Muslim conservatism is closely related to the changing urbanization phenomenon. It has been determined that the West completed the phenomenon of urbanization long ago and parallel to this, the conservative attitudes developed differently. On the other hand, with the degeneration of the phenomenon of migration, distorted construction and civilization, it was concluded that Muslims remained in the village-urban dilemma, which in a way led to the conflict between tradition and modernism. In addition, social reflex, imitation (acceptance of the sect ready in the family), the influence of the scholar in that geography and the spread of emigration, migration, emergence of a number of crises and breaks in the historical process, and as mentioned in the last analysis, the status of adopting sectarian identity as a general city It is closely related to the perception and attitude of sect in life.
\end{abstract}

Keywords: Urbanism, Conservatism, Modernism, East, West, Sect 


\section{Giriş}

Modernizmi kendi içinden eleştiren, ama ters bir süreçle kendi modernizmini üreten bir düşünce akımı olarak tanımlanan muhafazakârlığın "reaksiyoner gericilik" şeklinde etiketlenmiştir (Dural, 2004, s.121). Bu açıdan gelenek olgusu akımın temel referansıdır. Geleneği, bir takım olumsuz yargıların bulunmasına rağmen bir tür bilgelik olarak gören ve bütün bunların toplumsal tecrübelerin ürünü olarak kabul eden muhafazakar söyleme göre bilgi ve birikimler tek bir insanın ve düşüntülü yani karmaşaya açık aklının çabasıyla ortaya koyabileceği bir şey değildir. Bu itibarla toplumsal kaynaklı -ki bu ilahidir onlara göre- yani sosyal reflekslere göre şekillenen doğal akla güvenmek gerekmektedir. Bu nedenle meselâ, muhafazakâr düşüncenin ilk savunucularından biri olan 18. yüzyıl İngiliz düşünürü Edmund Burke (1729-1797), aklî prensipler bağlamında hareket eden Fransız tarzı devrimlere karşı kurumların devamlılığının, denenmiş pratiklerin ve yerleşik tarzların önemine vurgu yapmıştır (Erdoğan, 2004, s.5).

Günümüzde gerek Batıda gerekse Türkiye'de 'muhafazakâr' ya da 'muhafazakârlık' kavramı, toplumsal ve siyasal arenanın söylemsel boyutta adeta en temel unsurlarından birine dönüşmüş durumdadır (Duman, 2017, s.16). Ancak bu çalışmada muhafazakârlık kavramı kentleşme, kentlileşme ve mezhep algısı üzerinden incelemeye çalışılmıştır. Yani siyasal bir kavram olarak kullanılan bu akımın temel referanslarından biri olarak dine yaslanması konuyu bir şekilde dini tutum ve yorumlara ve oradan da doğal olarak mezheplerin dağılımına getirmektedir. Peki, bu durumun şehirli olma ile ilgisi ne bakımdan öne çıkmaktadır? Sorusu da çalışmanın son bölümünde tartışılacaktır.

Bu çerçevede İslam'ın tarih sahnesine çıkması ile oluşturmaya çalıştığ ve farklı isimlerle de anılan ideal bireyin kentli olması, olmasa da kentle bağının kopmaması gerekliliği İslam'ın bir mecburiyeti olarak değerlendirilmiştir. Zira kent sadece sosyal yaşantının canlı olduğu yer olarak değil aynı zamanda toplumu oluşturan diğer temel dinamiklere hayat veren bir ortak alan olarak anlam kazanmaktadır. Ayrıca şehirleşmenin din, dinin şehirleşme üzerine etkisin izleri Kur'ân'ın kullandığı yerleşim birimlerine ait kavramların tercihinde de kendisini göstermekte olduğu aşikardir ( Sicak, 2019: s. 756-757 vd.). 
Bu açıdan geniş İslam coğrafyasının her bir şehri mekân-kültür-din birlikteliğini yansıtan bir mozaiktir. Bu yapıların günümüzde geldiği durum bir yana tarih boyunca batıdan-doğuya fetih hareketleri ile beraber Bağdat, Basra, Kûfe, Fustat gibi şehirler kurulurken, doğuya bakıldığında ise Nişâbur, Merv, Semerkant ve Buhara gibi birçok şehir kurulmuştur. Şehirlerin kalabalıklığı yanında sahip oldukları kozmopolit yapı aynı zamanda bu mekânları özgür düşüncenin ve bilimsel faaliyetlerin zirvede olduğu coğrafyalar haline getirmiştir.

Kent kültürünün oluşmasında şüphesiz İslam'ın ibadet ve ahlak esaslarına bağlı olarak içerisinde barındırdığı kolektivizm etkilidir. Hz. Muhammed (s.a.v.)'e nispet edilen "'İnsan tabiatı gereği medenidir (toplumsaldır)" sözünün Peygambere ait olup olmadığı kesin olmasa da sosyokültürel bir tespit olması bakımından değerlidir. "İçtimâî hayat insanlar için bir zarurettir." ifadesi aynı şekilde İbn Haldun'un benzer bir bakış açısını yansıtması açısından önemlidir (İbn Haldun, 1990, s.100-106). O da bu sözüyle medenileşme ve şehirleşme bağına dikkat çekmiştir. Bu bağlamda ümran sözcüğü de bu bağın kavramlaşmış hali olarak ortaya çıkmiştır.

Sosyalleşme ve ibadetler arasındaki ilgi İslam dininde çok güçlü bir şekilde temellendirilmektedir. Örneğin salih amel yani yararlı, iyi ve güzel işler İslam dininde başkasına yapılan iyilikler kapsamında değerlendirilmektedir. Asr suresinde anlamını bulan kavram iman etmek ile birlikte anılmakta ve birbirlerine hakkı ve sabrı tavsiye eden inanların kurtuluşa ereceklerini müjdelemektedir. Hal böyle olunca sosyalleşme ile oluşacak kent kültürünün bedevilikten (olumsuz manada) daha sıhhatli bir toplum dokusu oluşturacağı gerçeği öne çıkmaktadır. Öyle ki cemaatle kılınan namazın bireysel olarak kılınan namazdan 27 kat daha faziletli oluşu, ayrıca Cuma namazının farziyyeti ve îfâsı için kent olarak sayılabilecek kalabalık bir yerin şart koşulması, bu durumu en net bir şekilde teyit etmektedir. İslam'ın en temel esasını oluşturan oruç, zekât, hac ve namaz, gibi ibadetlerin sosyal boyutu göz ardı edilemeyecek derecede ön plandadır. Tüm bunların istenilen düzeyde gerçekleşmesi ancak kentlileşmenin doğru bir şekilde organize edilmesi ile olmaktadır (Demirci, 2003, s.132).

Kentleşme ve kentlileşmenin birçok avantajları ve dezavantajları olduğu gibi oluşturduğu bir durum da muhafazakârlaşmadır. Bu durum aslında kentin doğasına terstir. Zira kentli birey kentin zorladığı yaşam 
tarzı sayesinde içine kapanamaması veya fasit dairede hareket edememesi gerekir. Muhafazakârlık ise soyut ve ideal olmanın ötesinde tarihsel mirasin tercih edilmesi şeklinde anlaşılabilir. Bu tercih, geleneksel olarak, toplumun organik bir anlayışına dayanmaktadır.

Yani muhafazakârlık, toplumun yalnızca bağları zayıf bireyler topluluğu değil, birbirine yakın ve bireylerden oluşan canlı bir organizma olarak var olmasını ifade etmesi açısından önem arz etmektedir. Nitekim bu çalışmada cevap aranmaya çalışılacak konu bu bağlamda ele alınmıştır. Diğer bir anlatım ile muhafazakârlık, kentleşmenin ürünü veya sonucu olamayacakken hangi şartlarla gündeme geldiğini ele alınıp, Doğu ve Batı bağlamında karşılaştırma yapmak önem arz etmektedir.

Çalışmanın bir diğer noktası da muhafazakârlığın temel referans noktalarından biri olan dini tutum ve davranışların ahlak ve davranış noktasında önceki neslin bir örneği olarak kurgulanması anlayışıdır. Selefi bir fikir söylemini çağrıştıran bu anlayışın mezhebi eğilimlere etkisi de ortadadır. Bu minvalde şehirlerin coğrafi veya kültürel manadaki niteliklerinin, sakinlerinin mezhepsel tutumlarına ne derecede yansıdığının tespit edilmesi zaruridir. Zira hangi mezhep daha şehirli hükmünü nasıl verebilir sorusunun cevabı mezhebin temel dinamikleri ile mi ilgilidir yoksa seküler bir takım yönelimlerle mi şehirler mezhebi karakterlere bürünmüştür? Örneğin Şafii mezhebi mensuplarının daha kırsalı Hanefi mezhebi mensuplarının da şehirli hayatını tercih ettikleri kabülü Şafii ve Hanefi mezheplerinin bir takım fetvalarına dayanarak yapmak ne kadar sağlıkl1dır? Özellikle ciddi bir göç ve haberleşme yeteneğinin arttığı düşünülürse kesin bir şehirli-taşralı ayrımı yapmak zor görünmektedir. Bu konudaki en basit fark köpeğin necis oluşu, deve tersi ile ilgili fetvaların varlığı veya tarım toplumuna özgü ellerin çok kullanılmasından kaynaklanan kanamaların oluşuna Şafii mezhebinin verdiği cevapların varlığı bu mezhebi kırsala özgü bir görünüme büründürmektedir. Bunun aksine Hanefi mezhebinin ticaret hayatı ile ilgili fetvalarının çokluğu veya kadın eline değmenin abdesti bozmayacağ ifadeleri de şehre özgü sorunlara verilen cevaplar gibi durmaktadır. Çalışmada bu kadar ayrıntılı konuları ele alıp bir akıl yürütme yapılmayacaktır. Buna karşın genel ülke nüfuslarının mezhep eğilimleri çerçevesinde mezhepsel algının muhafazakârlık ve şehirleşme ile ilgisini kurmaya çalışılmıştır. 


\section{Muhafazakârlık Kavramı ve Doğu-Batı Karşılaştırması}

Latince "conservare" ve Neo-Latin "conservatismus" (to conserve, preserve) kelimelerinden gelen "muhafazakârlık"(conservatism)'in sözlük manası "korumak" veya "olduğu gibi muhafaza etmek"tir. Bir şeyi korunaklı kılmanın sezgisini temsil eden bu kavramin nesnesi olan olguları Aydınlanmacı hareketin Kıta Avrupası'nda yarattığı değişim ve dönüşümün izleğinde kavrayan ilk dönem düşünürleri; kavramı doğuran sosyosiyasal dinamikleri her zaman kavram tanımının bir bileşeni olarak zikretmişlerdir (Gültekin, 2019, s.3). Ayrıca muhafazakâr kavramı bir Arapça kelime olan "muhafaza" ile Farsça kökenli olan "kâr" kelimelerinin birleşimi olarak ortaya çıkmıştır. Muhafazakâr kelimesi TDK tarafından tutucu kelimesi ile açıklanmış ve "Mevcut toplumsal düzeni, düşünceleri ve kurumları değiştirmeden olduğu gibi korumak isteyen (kimse), konservatör" şeklinde izah edilmiştir (TDK, 2019). Muhafazakâr fikirler ve doktrinler ilk olarak on sekizinci yüzyılın ikinci yarısı ve on dokuzuncu yüzyılın başlarında ortaya çıkmıştır. Bunlar, birçok açıdan Fransız Devrimi'nde ifadesini bulan büyük ölçekteki ekonomik ve siyasal değişim ve dönüşüme karşı bir tepkidir. Bu çerçevede muhafazakârlık Ancien Régime'e (Eski Rejim'e) dönmeye yönelik gelişen tüm bir eğilimleri izah etmektedir. Muhafazakarlığın dayandığı unsurlar olan; gelenek, pragmatizm, beşeri mükemmel olmayış, organizmacılık, hiyerarşi, otorite ve mülkiyet sözü geçen geriye yaslanmaya irca edilerek okunmalıdır (Heywood, 2017, s.35).

Muhafazakârlık başka bir ifadeyle değişimi genellikle beğenmeme veya güvenmeme inadı, özellikle de ani değişime direnme olarak değerlendirilebilir (dictionary.cambridge, 2019). Bu bağlamda değerlendirildiğinde, bir birey "muhafazakâr" elindekini koruyarak bir değer çıkacağını veya değerin korunan öncekilerden çıkacağ ifadesini bir tarz ve şart edinmiş kişidir (britannica, 2019). Doğu toplumlarındaki, muhafazakârlık, Batı' da konservativizm kavramı ile tam olarak örtüşmekte midir? Sorunu güncelliğini hala korumaktadır. Ancak kökeninde, doğasında ve özünde muhafazakârlık, konservatizm olarak anlamaya ve anlamlandırmaya çalışıldığında, eskiye sarılma olarak ortak paydasında buluştukları aşikârdır (Genç ve Coşkun, 2015, s.28-29). Hatta düşülen ortak hata ikisi de modernizme karşıymış şeklinde yapılan değerlendirmedir. Nitekim güncel siya- 
sal ve sosyal literatüre bakıldığında kavramın, sanayileşmeye ve kapitalistleşmeye bir direnç gösterme olarak algılanması durumu söz konusudur. Ancak muhafazakârlık özü itibariyle değişime karşı çıkmak ve eskiye tutunmak şeklinde anlaşılması gerekliliğinden hareketle modernizmin eskimesi veya ona tutunulması da muhafazakârlık göstergesidir (Duman, 2017, s.16-18).

Muhafazakârlığı en özgürlükçü veya en radikal bakış açılarından ayırmanın en kolay ve yaygın yolu, muhafazakârların, insanların ahlaki olarak siyasal ve toplumsal değişim yoluyla geliştirilebileceği konusundaki iyimser görüşünü reddetmeleri bağlamında düğümlenmektedir (Erdoğan, 2004, s.5-6). Dindar olan muhafazakârlar bazı şartlarda bu noktayı, insanların günahkâr olmasının suçu olduğunu söyleyerek ele alırlar. Şüpheci muhafazakârlar, yalnızca düşünülebilecek tüm siyasal ve sosyal koşullar altında, insanlık tarihinin büyük miktarda kötülükle dolu olduğunu değerlendirmektedirler (Akkaş, 2001, s.3). İnsan doğasının temelde iyi olduğuna veya insanların temel olarak rasyonel olduğuna inanmaktan ziyade, muhafazakârlar, insanların tutku ve istekleri tarafından yönlendirildiğini varsayma eğilimindedirler. Bu nedenle doğal olarak bencillik, anarşi, mantıksızlık ve şiddete eğilimli olduklarını varsayma eğilimindedir. Buna göre, muhafazakârlar, insanların temelini ve yıkıcı içgüdülerini engellemek için geleneksel siyasal ve kültürel kurumlara değer verir ve onu korumaya özen gösterirler (Okutan, 2013, s.129-130). Bu noktada ifade edilmesi gereken bir diğer önemli nokta bir davranış biçimi gibi değerlendirilen muhafazakârlık, aynı zamanda bir ideoloji olarak da ön plana çıkmaktadır. Ancak genel itibariyle tepkisel bir durum olan muhafazakârlık veya muhafazakârlaşmayı bir ideoloji olarak değerlendirmek çalışma bağlamında eksik kalacaktır.

\section{Kent, Kentleşme ve Kentlileşme Kavramları}

En temel tanımlaması ile nüfusunun çoğunun ticaret, sanayi, hizmet veya yönetimle ilgili alanlardaki işlerde çalışan ve o işlerle uğraşan, genel olarak tarım ve hayvancılık etkinliklerin olmadığı yerleşim alanına kent veya şehir denilmektedir (TDK, 2019). Diğer bir tanımlama ile birçok insanın yaşadığı, birçok konut, işyerleri, işletme vb. olan ve bir kasabadan daha büyük olan bir yer olarak tanımlanabilir (Keleş, 1980, s.70). 
Kent, klasik tanımlamalarının yanında yapılan yeni tanımlamalar genel itibariyle dört temel adımdan oluşmaktadır. Bunların hepsi "kentsel merkez" in varlığına dayanan yeni bir yüksek yoğunluklu popülasyon 1zgara hücreleri mekânsal konseptinin varlığına dayanmaktadır. Metrekare başına 1500 kişiden daha fazla yoğunluğa sahip tüm 1zgara hücreleri seçilir. Yüksek yoğunluklu hücreler daha sonra kümelenir, boşluklar doldurulur ve sadece minimum popülasyona sahip kümeler 50000 nüfusun 'şehir merkezi' olarak tutulduğu görülmektedir (Zengin, 2018, s.86-87). Nüfusunun yarısı şehir merkezinde olan tüm belediyeler (yerel idari birimler) kentin bir parçası olmak için aday olarak belirlenebilir. Nüfusun en az \% 50'sinin bir ülkede yaşadığı siyasal düzeye bir bağlantı olmasını sağlayacak şekilde tanımlanmaktadır. Kent merkezi ve kent merkezi nüfusunun en az\% 75'inin bir şehirde yaşadığı alan şeklinde de ifade edilmektedir (Dijkstra ve Poelman, 2012, s.2-3).

Kentleşme kavramı ise belirli bir zamandaki belirli bir durumu, yani kentlerdeki veya kasabalardaki toplam nüfusun veya alanın oranı olarak tanımlayabilir veya terim, zaman içindeki bu oranın artması olarak da anlaşılmaktadır (Göymen, 1982, s.81). Dolayısıyla, kentleşme terimi, toplam nüfusa oranla kentsel gelişim düzeyini veya kentsel oranın yükselme oranını temsil etmektedir. Kentleşme sadece modern bir fenomen değil, insan ölçeğinin küresel ölçekte hızlı ve tarihi bir dönüşümüdür. Bu sayede, ağırlıklı olarak kırsal kültür, hızla kentsel kültürün yerini alması şeklinde de anlaşılmıştır (sciencedaily, 2019).

Gelişmekte olan ülkelerin çoğu, özellikle sanayileşmeye başladıklarında, kentleşme sürecini yaşamaktadır. Şehirler ve kasabalar ticaret ve kültür merkezi haline gelir ve daha fazla insan bu sosyal ve finansal faydaların bazılarına erişmek için ülke dışına taşınır. Kentleşme, gelişmekte olan toplumun doğal bir parçasıdır, ancak onun dezavantajı da vardır. Şehir ve kasabalardaki nüfus arttıkça, genişler ve sonunda kırsal alanları işgal eder. Bir toplum olarak gelişmek istiyorsak, kentleşme ile denge sağlanmalıdır (conservation institute, 2019).

Kentlileşme, temel olarak bireylerin kentle bütünleşmesi manasına gelmektedir. Söz konusu bütünleşme kavramı genel itibariyle, belli bir sayıda bireyin daha büyük sayıda nüfusla kaynaşması manasına gelmektedir. Kentlileşme kavramı kentleşme akımı neticesinde sosyal hareketliliğin birey davranışlarında, hareketlerinde, ilişkilerinde, değer yargılarında, 
maddi ve manevi yaşam tarzlarındaki yaşanan değişimlerin meydana gelmesi olarak anlaşılabilir. Diğer bir ifadeyle 'kırlılıktan uzaklaşma, organize edilmiş sosyal hayata geçiş' olarak da kentlileşme izah edilebilir (Es ve Ateş, 2004, s.215)

\section{Kent ve Muhafazakârlık İlişkisinin Mezhep Merkezli Analizi}

Şehirler, aynı anda insani, maddi, doğal, söylemsel, kültürel ve organik olan iç içe geçmiş sosyo-uzamsal süreç ağlarıdır. Yiyecek, içecek, bilgisayar ve filmler gibi kentsel yaşamı destekleyen ve sürdüren sayısız dönüşüm ve metabolizma her zaman sonsuz birbirine bağlı çevresel ve sosyal süreçleri içerir (Swyngedouw 1999, s.444). Kır kültürü ise yaygın kan bağları, yakın ilişkiler ve toplumsal davranış ile karakterize edilirken, kentsel kültür uzak kan hatları, yabancı ilişkiler ve rekabetçi davranışlarla tanımlanır (Swyngedouw, 2004, s.9). Tönnis'in cemaat ve cemiyet (Gemeinschaft ve Gesellschaft) ayrımı da kırsal ve kent ayrımını yanşatması bakımindan önem arz etmektedir.

Bireyin kente gelmesi veya kentlileşmesi “bağımsızlığını” ve ekonomik fırsatlarını artırabilmesi olarak değerlendirilmektedir. Elbette kent yaşamı daha fazla "aydınlanmış" tutumları ve ayrımcı olmayan uygulamaları teşvik ederek eşitsizliğin doğurduğu açığını daraltabilir. Kentleşme, "ev dışında maaş kazanmayı ve güçlendiren ağlara katılımı bireyleri daha sosyal hale getirecektir" ifadesi kısmen doğru kısmen yanlış bir ifadedir. Zira sosyalleşme ağı bireylerin yaşam tarzları ve ilişki ağları ile alakalıdır. Kırsal alanlar, bireylerin kültürel, geleneksel ve bazı durumlarda dini uygulamalarla, muhafazakârlığa yönlenmesini neden olabilmektedir (Collins, 2008, s.273).

Köyden veya daha geniş bir ifadeyle kırsaldan kente gelen birey yeni yaşam tarzının getirdiği sorunlarla başa çıkma noktasında bir taşralı gibi hareket eder. Zira birey mekânsal olarak kentli ancak esasında kırlıdır. Bu çerçevede kırdan getirdiği yöntemleri uygulamak yoluna gider. Yani kendi Gemeinschaftını oluşturma veya mevcut birine dâhil olma yoluna gider. Bu çerçevede bireylerin hareketleri şekillenir. Nitekim birey zamanla bir Gesellschafta dâhil olsa dahi kendini bulduğu ve akrabalık ilişkilerinden öte kendini ait hissettiği Gemeinschafına bağlllık gösterir. Bun- 
lar günümüzde dernekler ve vakıflar şeklinde tezahür etmektedir. Bu dernekler ortak nokta ve hedefler üzerine kurgulandığı gibi daha çok hemşerilik ortak noktasında da kendini bulmaktadır. Aynı şekilde yasal bir dayanağ lum oluşumları da birey için kent yaşamının soğukluğu içerisinde bir çıkış noktası olarak değerlendirilebilir. Diğer bir anlatım ile belli yöntemlerle birey köyden kente geldiğinde daha muhafazakârlaşarak kendini ve etrafını koruma ve kollama içgüdüsüne kapılmakta bunu da modern ve modern olmayan yöntemlerin karışımı olan sivil toplum yöntemleri ile gerçekleştirmektedir. Söz konusu durum kentleşmenin bir süreç olarak devam ettiği toplumlar yani daha çok doğu toplumlarında yaşanan bir süreç olarak izah edilebilir. Zira kentleşme sürecini yüzyılı geçkin bir zaman önce tamamlamış batı toplumlarının kentlileşme diye bir sorunu kalmamıştır. Batı için kentleşme, modernleşme, sanayileşme ve sosyolojik rasyonalizasyon süreci ile yakından bağlantılıdır (sciencedaily, 2019). Bu ve benzeri diğer durumlar batı için çoğunlukla üstesinden gelinmiş konulardır. Ancak kentlileşmenin getirdiği sorunlar farklı boyutlarda batı toplumunda da devam etmektedir. Öyle ki kentli birey artık Gesellschaft ve getirdiği soğuk yaşam tarzını içselleştirmiş ve psikolojik olarak sürekli yıpranma yaşamaktadır. Bir manada kentlileşmiş ancak insani değerlerden uzaklaşmaya başlamıştır. Nitekim batı dünyasındaki topluma yön verenlerin insanları sivil topluma yönlendirme gayretinin altına yatan nedenlerin başında bu gelmektedir. Ne kadar sivil toplum kuruluşu olursa insanların o kadar çok kaynaşacağını ve bütünleşeceğini düşünmektedirler. Bu değerlendirme kısmen doğrudur. Ancak depolitizasyon problemi yani insanların belli standartları yakaladıktan sonra siyasetten soğumaları gibi desosyalizasyon da batı toplumunu esir almaya başlamıştır. Bu durumda batı toplumunda kendine has yeni bir muhafazakârlığı ortaya çıkarmıştır. Zira birey için günlük rutinler veya yaşam tarzının getirdiği her şey bir müddet sonra muhafaza edilmeye değer hale gelebilir. Bu çerçevede kentlileşmiş birey için muhafazakârlık farklılaşmış ve yeni bir anlam kazanmıştır. Örneğin, Amerika' da yaşanacak bir tayfun sebebiyle evlerinden ç1kamayacak olan insanlar temel ihtiyaçmış gibi sağlıksız sayılabilecek besinleri almayı tercih etmektedirler. Veya sinemaya gitmemenin eksikliğini duyup kentteki sinemanın kapatılmaması için kampanya başlatabiliyorlar. 
Şehirleşmenin din üzerine etkisi sanayi devrimi ile beraber farklı bir düzleme kaymıştır. Bu açıdan mevcut değişmelerin anlaşılmasında sanayileşme ile beraber dinin aldığı yeni şekil önemli bir referans noktası oluşturmakta ve din, bu çalışmada, yarattığı değer ve tutumlar açısından, insana neye, niçin ve nasıl bakması gerektiği konusunda sunduğu modelin kentleşme ve kentlileşme surecinde idrak ediliş tarzındaki şekliyle ele alınmalıdır. İnsanlığın her döneminde toplumların hayatını etkileyen, aşkın bir güce inanma duygusu var olmuş ve insanların yaşam biçimlerinin şekillenmesinde, sosyal, kültürel ve ekonomik alanların düzenleyen önemli bir unsur olmuştur. Bu gerçekliğe paralel bir biçimde sosyal değişmenin yavaş bir şekilde gerçekleştiği sanayi öncesi toplumlarda din özcü bir yaşam alanına sahipken, hızlı sosyal değişmelerin yaşandığı sanayi toplumlarında fonksiyonel bir tarzdadır (Arslantaş, 2008, s.180).

Köyden kente göç eden kişinin kente uyumunu sağlayan iki faktörden biri cemaat diğeri ise akrabalık bağlarıdır. Göçmen kişiler genelde önce, gecekonduda yaşayan akraba ya da ilişkisi olduğu bir cemaat yanına siğınmakla veya onlara yakın bir yerde ikamet etmektedir. İkamet bölgeleri ise genelde gecekondu bölgelerinden oluşmaktadır. Böylece gece kondu ya da değişik ideoloji veya inanç cemaatleri fertlerin yalnızlık hissine kapılmasına, yabancılık çekmesine, anomi yaşamasına engel olmaktadır (Arslantaş, 2008: 180). Toplumsal bünyede yaşanan büyük sosyal hareketlilikler ve dönüşümler, kişisel yaşantılardan, sosyal sistemin ve kültürün bütün katmanlarına kadar hemen her alanda eski ile yeninin karşılaşmasını gerilimli bir etkileşim süreciyle gündelik hayatın ve bilimsel tartışmaların odağına yerleştirmiştir (Yılmaz, 2002, s.63-82).

$\mathrm{Bu}$ açıdan her dönemin kendine özgü dinsel ve mezhepsel tutum ve davranışları var olagelmiştir. Aslında Doğu toplumlarında (özelde İslam ülkelerinde), muhafazakâr söylem daha ziyade dini gelenekle iç içe geçmiştir. Metropol şehirlerde bir cami veya medrese etrafında şekillenen dini cemaatler Avrupa'dan farklı olarak gelenekçi tutumu kutsamıştır. Zira kırsal yaşamın dinginliğinde, şehrin kaotik ortamına ayak basan bireyin kendisini en güvende hissettiği liman kendisi gibi düşünen ve yaşayan insanların bulunduğu ortamlardır. Avrupa' da ise dinden bağımsız bir liberal ve modernist söylem kendisine has muhafazakârlık olgusunu doğurmuştur. Konumuzla çok ilgisi olmasa iki coğrafya arasındaki fark aynı 
zamanda kapitalizme bakışta da kendisini hissettirmiştir. Batı'nın burjuvaziye açtığı savaş üzerinden ortaya çıkan değişim, Doğu da ise (özelde Türkiye) genelde esnaflar üzerinde varlığını doğurduğu için anti-kapitalist söylemler yerini kapitalizmin yararlı oluşuna bırakmıştır.

İstikrar ve düzenin dinsel tutumların da daha sağliklı olabileceğini savunan muhafazakâr söylemde yönetim anlayışı da iyi gelenekler üzerinden kurgulanmalıdır. Ayrıca göreceliğe karşı iman ve sezginin öne çıkarılması idarenin ilahi iradeye havale edilmesi muhafazakâr söylemin ana özelliklerindendir. Bütün bunlardan sonra karşımıza çıkan en önemli nokta "rasyonel akla" karşılık "tanrısal aklı" savunan muhafazakârlığın (Dural, 2004, s.123-124). Mezhebi tutumlar düzeyinde şehirleşme ile nasıl bir ilgisi olduğu sorusudur. Daha kabileci bir mantığa sahip olması dolayısıyla acaba mekânsal durum muhafazakâr mezhebi eğilimlere neden olmakta mıdır? Yoksa mekân-mezhep diyalektiğini kurmak hali hazırdaki veriler açısından imkânsız mıdır? Ayrıca şehirlilik açısından mezhep seçimi seküler bir takım saiklere mi yoksa tamamen teolojik nedenlere mi bağlıdır? Veya son tahlilde her şeyden bağımsız tamamen taklide dayalı bir davranış mıdır?

Yukarıdaki sorulara net bir takım cevaplar vermek elimizdeki veriler açısından çok da sıhhatli olmasa gerektir. Zira elde edilen bulgular bir mezhep hakkında tam rakamları vermek yerine kısmi veya tümü gibi belgesiz izahlarla ifade edilmektedir. Ayrıca bu tür rakamların daha isabetli bir şekilde belirlenmesi ancak saha çalışmaları ile mümkün olabilmektedir. Ancak bu konuda da yeterli çalışmalar mevcut değildir. Bu açıdan mezheplerin coğrafyalara ve şehirlere dağılımı üzerinden rakamsal kesinlik olmasa da genel bir takım istidlallerde bulunmaya ve mezheplerin dağılımının şehirleşme ile nasıl bir ilgisinin olduğunu ortaya koymaya gayret edilecektir.

Açıkçası muhafazakârlık ve mezhep algısı arasındaki korelasyonu kurmak basit bir mesele değildir. Zira her bir mezhep mensubunun muhafazakâr eğilimli olup olmadığının tespiti oldukça güçtür. Ancak mezhebin sahip olduğu iç dinamiklerin mensuplarınca kabul edildiği varsayımı üzerinden bir takım sonuçlar çıkarmak mümkündür. Bunun yanında şehirleşmenin getirdiği bir takım değişimler ve bireylerin eğitim olanakların artması ile birlikte kendisini herhangi bir mezhebe ait hissetmeyenlerin oranı da ülkeler arasında farklılık göstermektedir. Bu oranın kendisini 
"sadece Müslüman" olarak tanımlayanların oranı Pew'in 2012 yılında yaptığı araştırmaya göre önemli bir yekûn tutmaktadır. Buna göre Arnavutluk \% 65, Kosova \% 58, Bosna Hersek \% 54, Özbekistan \% 54, Kazakistan \% 74, Kirgizistan \%64, Endonezya \% 58, Mali \% 55 ile nüfusunun yarıdan fazlası kendini "sadece Müslüman" olarak tanımlamıştır. Azerbaycan $\% 45$, Nijerya, $\% 42$, Tunus $\% 40$ gibi oranlarla kendilerini "sadece Müslüman" olarak tanımlayan nüfuslarıyla listenin üst sıralarında yer almaktadır (Pew, 2019; Arıkan, 2018, s.350). Bu rakamların tahlil edilmesi farklı bir makalenin çalışma konusu olabileceğini söyleyerek şehirleşme ve muhafazakârlık açısından ne ifade ettiğini öncelikle genel Müslüman dünyasının rakamlarını da ortaya koyduktan sonra değerlendirmeye çalışılacaktır.

Öncelikle genel Şii-Sünni ana bloklar üzerinden rakamları ortaya koyalım. Daha sonra özelde Sünni, itikadi ve fıkhi mezhepler üzerinden değerlendirmelerde bulunulacaktır. Şii Müslüman dünyası denilince akla doğal olarak nüfusunun büyük bir bölümü Şii düşünceye sahip İran gelmektedir. Günümüz İran nüfusunun yaklaşık yüzde 80'ninin Şiîlerden oluştuğu tahmin edilmektedir. Bu nüfusun ana unsurları ise Lurları da ihtiva eden Farslar, kuzey-batıda Azeriler, güney-batıda Ahvaz ve çevresindeki Araplar, Hazar Denizi'nin güney sahilinde meskûn Gilân ve Mâzenderânlılar ile merkezde ve güneyde kalan çoğu Türk kökenli diğer halklardır (Izady, 2006, s.3; Büyükkara,2013, s.326-327).

İran, şehirleşme açısından mükemmel seviyede olmasa da ciddi bir kentli nüfusa sahiptir. Buradaki mezhep algısı tarihi kökenleri olan bir oluşumdur. Özellikle Sıffin savaşından sonra bloklaşan İslam âlemi Sünni-Şii ayrışımına maruz kalmıştır. Özellikle Emeviler'in baskıcı ArapSünni anlayışından uzaklaşan birçok Müslüman İran'a göç etmiş ve mezhep tercihlerini yapmışlardır. Mezheplerin tercih edilmesi yalnızca toplumsal saiklerle değil teolojik bir takım sebeplerle de olabilmektedir. Ancak şehre göç eden veya orada bulunan birey ait olma duygusu ve belki de kendini daha güvende hissetme açısından hâkim mezhebin kodlarını kolaylıkla benimseyebilmektedir. Bazen de yukarıda verilen örneklerde de mezhebe yabancılaşma veya kendini yalnızca Müslüman olarak ifade etme durumu ortaya çıkabilmektedir.

Toplumsal refleks, taklit (ailede hazır halde bulunan mezhebi kabulleniş), o coğrafyada bulunan âlimin etkisi ve yaydığı mezhep, göçler, tarihi 
süreçte ortaya çıkan bir takım krizler ve kırılmalar ve son tahlilde zikri geçen ifadelerde olduğu gibi mezhebi bir kimlik olarak benimsememe durumları genel şehir hayatı içerisindeki mezhep algısını ve tutumunu yakından ilgilendirmektedir. Örneğin toplumsal olarak birlikte hareket etme refleksi İran'ın Şii kimliğinin kristalize olmasına imkân sağlamıştır. 1979 İran İslam İnkılabı'nın bir ürünü olan anayasada "ebediyyen değişemeyecek" madde olarak geçen "devletin mezhebinin İsnâaşeriyye olduğu" şeklindeki ifade, diğer İslam mezhepleri açısından ister istemez dezavantajlı bir durumu ortaya çıkartmaktadır. Zira diğer mezhepler yönetim merkezinden uzaklaşarak ülkenin uç kısımlarına doğru yayılmışlardır (Büyükkara, 2013, s.327). Şehre ve şehirleşmeye uzaklık da bir bakıma bu mezheplerin kendi içerisinde muhafazakârlaşmasına neden olmakta ve azınlık psikolojisi ile mezhebi yönelimler kemikleşmektedir. Anlaşılan iki yönlü bir muhafazakârlaşmadan söz etmek mümkündür. İlki kalabalık olma ve beraber hareket etme davranışı buna karşı azınlık ve dışlanmış olma psikolojisi altındaki birlikteliktir.

Göç olgusu, herhangi bir mezhebin bulunduğu yerden başka bir yere gidişi ile yeni yerleşim yerindeki mezheple karşılaşmasına imkân tanımaktadır. Bu durum iki şekilde meydana gelmektedir. Ya mezhepsel bir aynılık durumuna binaen kırsaldan şehre göç eden kişiler şehrin dokusuna çabucak uyum sağlamakta ve birlikte yaşamakta da bir zorluk çekmemektedir. Ya da iki farklı mezhebin kent hayatında karşılaşması durumu ortaya çıkmaktadır. Şehre hangi mezhebin hâkim olacağına açıkçası göçün getirdiği kalabalığın niceliği etki etmektedir. Diğer taraftan başka bir bölgeden gelen ünlü bir âlimin varlığı etrafında oluşacak mezhep müntesipleri halkasını genişletebilmektedir. Örneğin Pakistan, Hindistan ve Afganistan'ın bulunduğu bölgede Şiiliğin yayılmasının temelinde Safeviler dönemi ve daha sonraki zamanlarda İran'dan gelen yoğun Şii nüfusunun etkisi vardır. Ayrıca 1947 yılında Avaz bölgelerinden Pakistan'a göç eden çok sayıda Şii-İsnâaşeri nüfus hem ülkenin hem de göç ettikleri şehrin mezhep dokusunu değiştirmişlerdir. Bu göç olgusu içerisinde dikkat çeken diğer önemli hususa örnek olarak âlimin durumunu zikretmiştik. Bu açıdan 1800'lerin başında Şeyh Zeynulâbidin Mâzenderânî'nin Hindistan'a getirilmesi ve onun rehberliğinde din faaliyetlerinin sürdürülmesi ciddi bir Şii bilincin ve nüfusun oluşmasına olanak sağlamıştır (Büyükkara,2013, s.329-330). Ancak bunlara rağmen günümüzde ciddi bir 
Sünni nüfus yoğunluğu göze çarpmaktadır. Izady, Pakistan'da dini durum haritasında nüfusu \% 76,3 Sünnî ve tamamen Hanefi, bu Hanefiler \% 49 Birelvî, \% 27,2 Diyûbendiler olarak, Şiîler ise toplamda \%19,1 olup \% 17 İsnâaşeriyye, \% 2 İsmaili şeklinde, Kadıyânîler/Ahmediler ise \% 1,7 olarak göstermektedir (gulf2000, 2019). İsnâaşeriyye'nin nüfus içindeki dağ1lımı yukarıda zikri geçen göç ve âlim etkisinin şehir-mezhep ilişkisini nasıl belirlediğine bir örnek olarak değerlendirilebilir. Zira Afganistan nüfusu içerisindeki Sünni-Hanefi nüfusun yoğunluğu da bu mezhep âlimlerinin bölgedeki Hanefi kültürünü benimsemiş olmaları ile açıklanabilir (gulf2000a, 2019). Bazen de şehrin hâkim mezhebi dişarıdan geleni de etkilemektedir. Irak nüfusunun büyük bir bölümünün Şii'lerden oluşuyor olması şehirden kente göç eden birçok Sünni Bedevi kabilelerin Şiileşmesine neden olmuştur. Irak mezhebi demografinin göçlere ve savaşlara rağmen halen varlığını ağırlıklı olarak Şiilik üzerinden sürdürüyor olması da bunu göstermektedir. Zira toplam nüfus içerisindeki Şii oranı \%62 civarındadır (gulf2000b, 2019). Bu durum karşılıklı bir muhafazakâr söylemi geliştirmiştir denebilir. Hükümete sahip olan Şiiler'in iktidarı devam ettirme adına ortaya koydukları korumacı tavra karşılık Sünnî zümrelerin de hak arayışlarını muhafazakâr söylemi aşacak şekilde şiddete yöneltmelerine de neden olmuştur. Son zamanlarda meydana gelen Sünnî kaynaklı şiddet eylemleri yaklaşımı doğrulamaktadır. Deniz üzerinden yapılan göçler Yemen ve Umman Müslümanlarıyla ilişki kuran Hindistan'ın güney-batı ve güney sahilindeki; Kerala, Karnataka, Maharashtra, Tamil Nadu eyaletlerindeki Müslümanlar ile Sri Lanka ve Maldiv adaları halklarının ise Şafii mezhebine mensup olmalarını sağlamıştır (Büyükkara, 2013, s.348).

Mezhep âliminin ortaya çıtığı bölge o coğrafyada yer alan birçok kentin ve etnik topluluğun mezhep seçimini etkilemiştir. Örneğin Maveraünnehir ve Türkistan denilen bölgelerde Hanefi mezhebinin etkinliği ancak bununla izah edilebilir. Türk kökenliler (Türkiye ve Kıbrıs Türkleri, Türkmenler, Özbekler, Kazaklar, Kırgızlar ve Uygurlar), Tacikler genelde bu mezhebe mensuptur. Yakın bölge olması dolayısıyla ve kentlileşme ile beraber ortaya çıkan şehir hayatı mezheplerin etkileşimini artırmış ve alt kıtadaki Afganistan, Pakistan, Hindistan, Keşmir ve Bangladeş Müslümanlarının büyük çoğunluğu Hanefi mezhebini tercih etmiştir. 
Âlimin etkisine diğer bir örnek de Kuzey Afrika Müslümanlarının genelde Sünnî-Mâlikî olmasıdır. Adından da anlaşılacağı üzere İmam Mâlik b. Enes el-Asbahî el-Yemenî (ö. 179/795)'nin Yemenli olması bunun en önemli sebebidir (gulf2000c, 2019). Bu mezhep varlığını Güney Sudan'da Şafii mezhebi ile birlikte sürdürmektedir (gulf2000-4, 2019).

Bunun yanında etnik köken genelde mezhep seçimini de genel olarak etkileyen bir durum olarak göze çarpmaktadır. Bazen göç etse de veya daha sonradan farklı sebeplerle coğrafya değiştirse de topluluklar benzer mezheplere sahip olabilmektedir. Zira Türklerin aksine Araplar Şafii mezhebine mensuptur. Filistin, Ürdün, Hicaz, Yemen ve Umman'daki Arap Müslümanlar genelde Şafii'dir (gulf2000d, 2019). Bunun yanında Sünni Kürtlerin Şafii mezhebine mensup oluşunun temelinde Araplarla daha çok ilişki kurmaları yatmaktadır denebilir (Arıkan, 2013, s.348).

Toplumsal refleks ve politik faaliyetlerin bir şehrin mezhepsel demografisinin nasıl etkilenebileceğine Lübnan örneği isabetli görünmektedir. Lübnan'da şehirli bir kimliğe sahip Sünnilerin aksine Şiiler kırsal kesimlerde yaşamaktadırlar. Eğitim seviyesi de buna paralel olarak düşük olan bu kesimlerin Musa es-Sadr'ın (ö.1978) devam ettirdiği siyasal ve kültürel faaliyetler Şii nüfusun seviyesini ciddi bir biçimde arttırmıştır (gulf2000e, 2019). Özellikle Hasan Nasrallah'ın İran ile uyumlu politikalarının da Lübnan Şia'sı üzerinde ciddi etkileri vardır (Momen, 2019, s.158-160). Politika-teoloji uyumu mezhepsel güç algısını arttırmaktadır. Böylece mezhep güçlendikçe muhafazakâr söylem de yükselmektedir. Şiilik bilincinin artmaya başlaması da şehir hayatındaki mezhep mensuplarının mezhebi bir etnik kimlik gibi kullanmaya başlamalarına neden olmuştur. Bu durumun farklı bir örneği de siyasal sahada ciddi bir güç kaybı yaşayan Pakistan'daki Şii unsurlar birçok Sünni kökenli örgütün hedefine oturmuş olmasıdır (Büyükkara, 2013, s.331).

Şehirleşmenin mezhepler üzerindeki önemli sonuçlarından biri de demokratik katılım hakkının ortaya çıkmasına binaen mezheplerin bulundukları kentlerde temsil etme refleksini geliştirmeleridir. Bu durum doğal olarak oy verme sürecinde ciddi bir etkiye sahip olmaya başlamıştır. Seçim sonucu ortaya çıkan tablonun değeri mezhep mensuplarının sahip oldukları bölgelerde icra ettikleri yüksek mevkili görevlerde ortaya çıkmaktadır. Örneğin Bahreyn Şiîlerinin siyasal partisi el-Vefâk 2010 seçimle- 
rinde en fazla oyu alarak İslamcı ve Selefi partileri geride bırakıp parlamentoda çoğunluğu ele geçirmiştir. Kuveyt'teki Aralık 2012 genel seçimlerinde Şiî adaylar meclisteki 50 sandalyeden 17'sini kazanmayı başarmıştır. Siyasal partilere izin verilmeyen Suudi Arabistan'da ise Şeyh Hasan es-Saffâr gibi âlimler etrafında hak arama mücadelesi ise sürmektedir (Büyükkara, 2013, s.329).

Günümüzde halen devam eden Suriye iç savaşının önemli katalizörlerinden biri de mezhep algısının muhafazakârlaşmasıdır denebilir. Özellikle emperyal güçlerin etnik siyasetten daha ziyade mezhepsel farklılıklar üzerinden uyguladıkları ayrıştırıcı politika bir bakıma onlar açısından meyvelerini vermiştir. Şii ve Sünni oluşumların bu süreçte ciddi kayıplar verdiği bir kazananın olmadığı ortadadır. Genel kentli nüfusun artışı ve şehirleşme ile beraber siyasal haklara sahip olma noktasında ortaya çıkan iktidar kavgası Suriye için hep sorun olagelmiştir. 1949 ve 1963 darbeleri ile mevcut Sünni subayların çoğu tasfiye edilince, alt kademedeki Nusayri subayların etkinliği arttı ve Nusayriler kilit noktaları ele geçirmeye başladılar. Bununla beraber Mezhep, bölge ve aşiret bağlarının iktidar mücadelesinde kullanılması, Sünni Müslüman elitin Suriye'deki hâkimiyetini kırmaya odaklanmış Baas ideolojisiyle örtüşmekteydi. Kırsal kökenli azınlıklar kendi mezheplerinden, bölgelerinden ya da aşiretlerinden gelenler aracılığıyla yapılanmayı, Sünni Müslüman karşıtlı̆̆ıla mücadelede gerekli bir örgütlenme modeli olarak görmüşler ve Baas içerisinde örgütlenmişlerdir (Bağlıŏlu, 2013, s.500-504). Kırsaldan kente göç eden yığınların bu hak arayışları kentlileşme için gerekli olan altyapı hizmetlerinin ve sosyal hakların da sağlanamaması üzerine kontrolsüz yığınların artmasına neden olmuştur. Muhafazakâr söylemin de bu süreçte arttırılarak safların sıklaştırılması meseleyi şuan için içinden çıkılmaz bir kaosa sürüklemiştir.

Sünnî ve Şii olarak iki ana gövdeye ayrılan İslam coğrafyası kentlileşme ve kentleşme açısından da ciddi sorunlarla karşılaşıyor olmaları hem muhafazakârlık hem mezhep algısının bir bakıma paralel seyretmesine neden olmaktadır. Göç dalgaları mezheplerin karşılaşmalarını sağl1yor olsa da her bir mezhep mensubu kendi etrafında ördüğü korumac1 duvar ile varlığını sürdürmeye çalışmaktadır. Globalleşen dünyada etkileşimlerin artması dahi mezhep mensubiyeti noktasında ciddi ve radikal 
değişimleri kabul eder gibi görünmemektedir. Bunun aksine mezhepsizlik veya kendini hiçbir mezhebi kimlik ile ifade etmeme durumu sekülerleşmenin getirdiği ilginç bir durum olarak göze çarpmaktadır. Şehrin genel kozmopolit yapısı içerisinde daha hızlı bir değişimin yaşanması beklenirken muhafazakârlığa karşıt bir durum olarak yabancılaşma öne çımaktadır. Ayrıca küresel iletişim ağlarının internet ile zirveye çıktığı düşünülürse değişimin daha hızlı olması beklenirken muhafazakâr mezhep algısının artması bireylerin şehrin kaosundan korkmaları ve kendilerini benzer topluluklar içerisinde tutarak korumaya çalışmaları ile açıklanabilir. Bütün bunları göz önünde bulundurduğumuzda sonuç olarak İslam dünyasında mezhep algısını teolojik hazır bulunuşluluk ile açıklayabiliriz. Taklide dayalı bu oluşum bireylerin anadil öğrenir gibi ana-mezhebe mensubiyet geliştirmelerine neden olmaktadır. Pratikte kentlileşmenin getirdiği bütün unsurları içerisinde barındıran birey son tahlilde mezhebi algısını önceden kendinde bulunan hazır kodlara göre oluşturmaktadır. Haritaları incelediğimizde de mezheplerin bloklar halinde her bir kentte yer alıyor olması da bu savı doğrulamaktadır.

Batıya bakıldığında ise mezhep-muhafazakârlaşma ve kentlileşme arasında doğuya göre anlamlı bir ilişki kurmak zor görünmektedir. Katolik muhafazakâr eğilimin, baştan beri ağırlıklı olarak yer aldığı Avrupa kıtasında reform hareketleri ile başlayan başkaldırı bir bakıma Avrupa mezhep demografisini etkilemiştir (worldatlas, 2019). Ancak Fransız ihtilali ve onun beraberinde getirdiği Aydınlanma dönemi muhafazakâr mezhep ve şehirleşme ilişkisini farklı bir noktaya getirmiştir. Özellikle Fransız devrimi ile ortaya çıkan duruma teknokratların ve toprak ağalarının geliştirdiği muhafazakâr söylem eskiyi koruma refleksi olarak öne çıkmıştır. Ancak Avrupa bir bakıma şehirleşme ile birlikte demokratik kazanımları da sağlamayı başarmıştır. Bunun yanında laiklik ile beraber de kentlileşme bir bakıma dini yapıdan bağımsız bir yapıya bürünmüştür. Din kamusal alandan uzaklaştırıldığı için vicdanlara ve sübjektif tercihlere bırakılmıştır. Bu da Doğu'dan farklı olarak "blok mezhepli kentli hayatının" ortaya çıkmasını engellemiştir. Ancak buna rağmen her bir etnik yapı kendisini mensup olduğu mezhep ile tanımlamaya devam etmektedir. Örneğin yan yana bulunmalarına rağmen Hırvatların Katolik, Sırpların Ortodoks olması bununla açıklanabilir. Yani burada da bir etnisite-mezhep diyalektiği öne çıkmaktadır. Genel olarak Batı'da da nüfusun büyük bir kısmının 
Katolik olması yine Doğu için yapılan istidlale benzer bir şekilde teolojik ve taklit temellidir. Zira Avrupa nüfusunun yarısı Katolik'tir. Ancak İslam dünyasının aksine Batı'da yaşanan reform hareketleri meyvesini vermiş ve nüfusun \%37'sinin Protestan mezhebini benimsemesini sağlamıştır. Ortodoks nüfus ise \%12 civarında kalmıştır (pewforum, 2019).

Özet olarak; Katolik Kilisesi'nin inançlarıyla özdeşleşen 1 milyardan fazla insan mevcut. İkinci sırada Protestanlık yer almaktadır. O da yaklaşık olarak 920.000.000 kişi civarındadır. Ancak, ilginç bir argüman olarak; Protestanları protesto edenlerden ayırmaya gelince, farklılıklar biraz bulanık görünmektedir. Örneğin, bazı din âlimleri, Anglikanların Protestanlığın bir parçası olduğunu savunmaktadırlar. Bu mantığa göre, dünyada Protestanlığı uygulayan yaklaşık 1,5 milyar insan var. Bu rakam Protestanlığı, yaklaşık 1,3 milyar olan Katoliklerin takip ettiği en popüler mezhep haline getirecektir (worldatlas, 2019).

Siyaset felsefesinin kadim tartışmalarından birisi olan ferdin mi yoksa cemaatin mi temel haklarda önceliği olduğu meselesine özgürlükler bağlamında temas etmek gerekebilir. Anlaşılacağı gibi mezhepleri ve dinî cemaatleri de içine alan sosyal gruplar, kendileri için varoluşsal önemi bulunan geleneği korumak adına, kendi mensuplarının özgürlüklerini kısıtlayan bir yasal güç elde etmek istemektedirler. Tarihsel gerçekler göstermektedir ki kentlileşme olgusu yükselse dahi kökenleri ne olursa olsun dinler ve mezheplerin, kendi aralarından çıkan farklı seslere ve muhalif duruşlara gösterdikleri hoşgörüsüzlük ve karşıtlık, başka din ve mezheplere karşı gösterdiklerinden daha ağır ve şiddetli olmaktadır. Yani muhafazakârlık kendi bünyesinde daha şiddetli bir cereyan olarak güncelliğini korumaktadır (Büyükkara, 2013b, s.126).

\section{Sonuç}

İnsanların bu benzeri görülmemiş hareketinin önümüzdeki birkaç on y1l içinde devam edeceği ve yoğunlaştığı, mantar gibi türeyen kentlerin sadece bir yüzyıl önce anlaşılamayan boyutlarda tutacağı tahmin edilmektedir. Günümüzde Asya'da, Dakka, Karachi, Mumbai, Delhi, Manila, Seul ve Pekin'in kentsel toplulukları hâlihazırda 20 milyondan fazla kişiye ev sahipliği yaparken, Pearl River Delta (İnci Nehir Deltası), Şangay-Suzhou 
ve Tokyo'nun önümüzdeki on yılda 40 milyon kişi yaklaşması veya aşması beklenmektedir. Asya dışında, Mexico City, Sao Paulo, Lagos ve Kahire, 20 milyondan fazla insana ev sahipliği yapıyor ya da çoktan bu sayıy aşmış durumdadır. Ancak bu kentleşme söz konusu ülkelerin büyük çoğunluğunun kültürel kodlarına aykırı bir süreç olarak ortaya çıkmaktadır. Doğunun özellikle bir kısmının kendi kentleşmesini batıya göre çok önce yaşamasına rağmen bireylerin ve toplumların batı tarzı kentleşmeye mahkûm kalması ciddi problemleri beraberinde getirmektedir. Özellikle Avrupa'daki kentlerin belli regülasyonlar sayesinde kisttlanan veya regüle edilmese dahi sabit kalan nüfusu ve müreffeh toplumlar oluşu çok dar bir alanda dahi olsa Avrupa'yı yaşanır kılmıştır.

Günümüz dünyasında diğer insan faaliyetlerinin yanında kentleşme de, Kur'ân'da varlık aleminin diğer dengeleri olarak kabul edilen ( Çalışkan, 2017: s.248 vd.) hayvan ve bitki türlerinin nesline zarar vermektedir. Bunun temel nedeni, kentleşmeden kaynaklanan habitat değişiminin hem sert hem de giderek yaygınlaşmasıdır (Mckinney, 2006, s.247). Bunun yanında kentleşmenin acımasız yönü insanların tarih boyunca sürdürdüğü yaşam tarzına da zarar vermektedir. Günümüz kenti batı medeniyetinin bir ürünüdür ve bu ürün diğer toplumların ürettiği her şeyi yok etmektedir. Bunun en büyük göstergesi de kentleşme alanında kendini hissettirmektedir. Özellikle İslam dünyasının kendine has bir gelenek sunduğu veya en azından çerçevesini çizdiği kent bir kenar bırakılmıştır. Müslümanlar batı tarzının çok kötü bir kopyası olan kentlerde yaşamaya mahkûm edilmişlerdir.

Doğu veya Müslüman kentleri batı kopyası olsa dahi muhafazakârlıkları farklı tezahür etmektedir. Zira kültür kodlarındaki farklılıklar başka yansımalar neden olmaktadır. Bu çerçevede doğu toplumunun kentleşme sürecinin devam etmesi onları daha sınırlı ve dar bir perspektifte yaşama kırlı olmaları ve değişime direnmeleri bağlamında itmektedir. Aynı şekilde batı toplumunda ise kentli olmalarına ve geniş bir perspektifte olmalarına rağmen değişime direnme ve kendilerini içe kapatma şekliden meydana gelmektedir. Diğer yandan günümüz kent dindarlığının ve kapitalizmin bir nedeni/sonucu olan Protestanlığın ortaya koyduğu ahlakın artık sadece Hristiyanlığa özgü bir şey olmaktan çıkması Müslüman ve diğer dinlere inanan toplumlarda benzer şekilde gelişmesi de kentliliğin ortak bir yansıması olarak ele alınabilir. 
Mezhebi tutumlar düzeyinde şehirleşme ile nasıl bir ilgisi olduğu sorusunun cevabında öne çıan başlıkların teolojik ön kabul yani aileden taklit yoluyla elde edilen kazanımın sürdürülmesi durumu. Diğeri ise göç; bu noktada ise karşılık etkileşim olsa da İslam dünyasında mezhebi manada değişimler sınırlı düzeyde gerçekleşmektedir. Daha ziyade politik söylemi güçlü olan mezhep şehre hâkim olmaktadır. Ayrıca âlim veya veli bir zatın mensup olduğu veya desteklediği mezhep kentli nüfusun âlimin görüşlerini takip etmesine binaen âlim-mezhep özdeşliğini kurdukları görülmektedir. Bulunulan coğrafyadaki eğitim ve iletişim olanakları mezhep değişiminden ziyade mezhebe karşı yabancılaşma veya kendini herhangi bir mezheple tanımlamama durumunu ortaya çıkarmaktadır. Ancak şehre hangi mezhep hâkimse eğitim seviyeleri ne olursa olsun her bir mezhep mensubunun ciddi muhafazakâr söylemlere sahip olduğu anlaşılmaktadır. Hali hazırdaki veriler açısından kentlileşme ve mezhep algısı arasındaki ilişkiyi kurmak oldukça zor görünmektedir. Büyükkara'nın belirttiği gibi bu konuda ciddi bir enformasyon eksikliği mevcuttur. Bu itibarla bilimsel metotlarla demografi-mezhep diyalektiğini kuracak çalışmalara ciddi ihtiyaç göze çarpmaktadır. Saha çalışmalarının yapılması bu konudaki eksikliği tamamlayacaktır. Ancak bu çalışmalar içerisine şehirleşme olgusunun ortaya çıkardığı seküler durumun etkilerini de eklemek yerinde olacaktır. 


\title{
EXTENDED ABSTRACT
}

\section{Relationship between Geography and Religion; Comparison of East and West in the Context of Urbanization, Conservatism and Denomination Demographics}

\author{
Abdullah Aydin - Yusuf Okşar \\ Mustafa Kemal University
}

Conservatism, defined as a stream of thought that criticizes modernism from within, but produces its own modernism through an inverse process, is labeled as "reactionary reaction" (Dural, 2004, p.121). In this respect, tradition is the main reference of current. According to the conservative discourse that considers tradition as a kind of wisdom despite the existence of some negative judgments, knowledge and accumulation is not something that a single person can put forward with the effort of the speculative mind. In this respect, it is necessary to rely on the natural mind, which is shaped according to social reflexes of social origin - which is divine to them. Thus, for example, the 18th century British thinker Edmund Burke (1729-1797), one of the first defenders of conservative thought, emphasized the continuity of institutions, tried practices and established styles against French-style revolutions acting in the context of rational principles (Erdoğan, 2004, p.5).

Today, both in the West as well as in Turkey 'conservative' or 'conservative' concept, which has turned into one of the social and political arenas at almost the most basic elements of discursive dimensions (Smoke, 2017 , p.16). However, in this study, the concept of conservatism; urbanization, urbanization and sectarian perception. In other words, leaning on religion as one of the main references of this movement, which is used as a political concept, brings the issue to religious attitudes and interpretations and then naturally to the distribution of sects. But how does this relate to being a citizen? The question will be discussed in the last part of the study. 
In this context, the necessity of Islam to be formed by the emergence of Islam on the stage of history and the ideal individual, who is also known by different names, and not to break with the city, has been evaluated as an obligation of Islam. This is because the city has a meaning not only as a place where social life is alive, but also as a common area that gives life to the other fundamental dynamics that make up the society.

In this respect, each city of the wide Islamic geography is a mosaic reflecting the unity of space, culture and religion. Aside from the situation of these structures, the cities of Baghdad, Basra, Kufa, Fustat have been established along with the conquest movements from west to east throughout history, and many cities such as Nisabur, Merv, Samarkand and Bukhara have been established. Besides the crowds of cities, the cosmopolitan structure they have also made these spaces geographies where free thinking and scientific activities are at the peak.

Undoubtedly, the collectivism of Islam, depending on the principles of worship and morality, is effective in the formation of urban culture. Hz. Muhammad (s.a.v.) "Relative to the" "human nature is civilized (social)" is not certain whether the word belongs to the Prophet, but it is valuable in terms of a socio-cultural determination. The expression hayat social life is a necessity for human beings ayn is also important in that it reflects a similar perspective of Ibn Khaldun (Ibn Haldun, 1990, p.100-106). With this promise, he drew attention to the bond of civilization and urbanization.

The interest between socialization and worship is strongly grounded in the Islamic religion. For example, righteous deeds, useful, good and good works are considered within the scope of goodness done to someone else in Islamic religion. The concept of meaning in Surat al-Asr is mentioned together with faith and heralds the belief that those who advise each other the right and patience will come to salvation. In this case, the fact that the urban culture that will be formed by socialization will create a healthier society texture than the Bedouin (negative sense) comes to the fore. In fact, the fact that the prayer made by the congregation is 27 degrees more virtuous than the individual prayer, as well as the necessity of a place that can be considered as the city for the prayer and performance of Friday prayer, this situation confirms this situation clearly. The social dimension of worship such as fasting, zakat, pilgrimage and prayer, which 
constitute the most fundamental basis of Islam, is in the foreground. The realization of all these at the desired level, but the right way is to organize urbanization (Demirci, 2003, p.132).

There are many advantages of urbanization and urbanization as well as conservativism. This is contrary to the nature of the city. Because the urban individual should not be able to move inside or move in a flat apartment thanks to the life style forced by the city. Conservatism can be understood as preferring historical heritage beyond being abstract and ideal. This choice has traditionally been based on an organic understanding of society.

In other words, conservatism is important in terms of expressing the existence of society as a living organism that is close to each other and not only as a group of individuals with weak ties. As a matter of fact, the subject to be sought for answers in this study was discussed in this context. In other words, it is important to make a comparison in the context of East and West by considering the conditions under which conservatism cannot be the product or result of urbanization.

Another point of the study is the conception of religious attitudes and behaviors, which is one of the main reference points of conservatism, as an example of the previous generation in terms of morality and behavior. This conception, which evokes a predecessor discourse, has an impact on sectarian tendencies. In this context, it is essential to determine the extent to which the geographical or cultural characteristics of the cities are reflected in the sectarian attitudes of the inhabitants. Because the answer to the question of which denomination is more urban and how can we judge the basic dynamics of the denomination, or did the cities become sectarian characters with a number of secular orientations? For example, how healthy is it to make the determination that the more rural members of the Shafiite sect prefer the urban life of the members of the Hanafi sect? It seems difficult to make a definite urban-provincial distinction, especially considering that a significant migration and communication ability has increased. The simplest difference is the dog's najiis, the presence of fatwa related to camel inverse or the bleeding of Shafi'i sects to the occurrence of bleeding caused by the use of hands specific to agricultural society. On the contrary, the Hanafi denomination of the abundance of fatwas related to the commercial life, or expressing that touching the hands of women 
does not disturb the ablution seems to be the answers to the specific problems of the city. In this study, we will not address such specific issues and make any reasoning. However, within the framework of the sectarian tendencies of the general population of the country, it was tried to establish the relevance of sectarian perception to conservatism and urbanization.

\section{Kaynakça / References}

Akkaş, H. H. (2001). Türk modernleşme tarihinde muhafazakâr siyasi düşünce. Afyon Kocatepe Üniversitesi Sosyal Bilimler Dergisi, 3(2), 241254.

Arıkan, A. (2018). İslam dünyasının mezhep haritası ve nüfus dağılımı. Journal of Islamic Research, 29(2), 348-79.

Arslantaş, H. A. (2008). Sosyal değişme, kentleşme ve kentlileşmenin din üzerine etkileri. Illahiyat Fakültesi Dergisi, 13(2), 171-198.

Bağlıoğlu, A. (2013). Suriye'de Mezhep hareketlerinin güncel siyaset üzerine etkileri. e-makâlât Mezhep Araştırmaları, 6(2), 495-523.

Büyükkara M. A. (2013b). Mezhepsel uzlaşma ve barış: Modern ve postmodern yaklaşımlar. Dîvân Disiplinlerarası Çalışmalar Dergisi, 18(35), 109138.

Büyükkara, M. A. (2013). İslam kaynaklı mezheplerin Ortadoğu'daki Coğrafi dağılımı ve tahmini nüfusları. e-makâlât Mezhep Araştırmaları, 6(2), 321-354.

Çalışkan, N. (2017). Kur'an'da insanın varlıklarla ilişkisi. The Journal of Academic Social Science Studies, 552017, 247-265

Collins, L. (2008). Confronting urbanization and the AIDS epidemic: A Doubleedged sword, the new global frontier, urbanization, poverty and environment in the 21st century. In (Ed. G. Martine, G. McGranahan, M. Montgomery, R. Fernández-Castilla), VA USA:Earthscan publishing.

Demirci, M. (2003). İslam'da şehir ve şehrin sosyal dinamikleri. İstem, 1(2), 129-146,

Dijkstra, L. ve Poelman, H. (2012). Cities in Europe the new OECD-EC definition, Regional Focus, Regional and Urban Policy. https://ec.europa.eu/regional_policy/sources/docgener/focus/2012_01_city.-pdf, Erişim Tarihi: 25.04 .2019 
Duman, F. (2017). Muhafazakâr ideolojide farklı düşünce gelenekleri bağlamında muhafazakârlı̆̆ın doğası. Hitit Üniversitesi Sosyal Bilimler Enstitüsü Dergisi, 10(1), 15-34.

Dural, A. B. (2004). Muhafazakârlığın tarihsel gelişimi ve muhafazakâr söylem. Muhafazakâr Düşünce, 1(1), 121-133,

Erdoğan, M. (2004). Muhafazakârlık: Ana temalar. Liberal Düşünce Dergisi, 34, 5-9.

Es, M. ve Ateş, H. (2004). Kent yönetimi, kentlile şme ve göç: Sorunlar ve çözüm önerileri. Sosyal Siyaset Konferansları Dergisi, 48, 205-248.

Genç, E. ve Çoşkun, T. (2015). Muhafazakârlık ve Türkiye muhafazakârlıklarının bazı halleri. Niğde Üniversitesi Ikktisadi Ve İdari Bilimler Fakültesi Dergisi, 8(1), 27-40.

Göymen, K. (1982). Kentle bütünleşme sürecinin yönetsel boyutu:Kentle bütünleşme. Ankara: TGAV yayını.

Gültekin, Ö. (2019). Muhafazakârllk üzerine. 1-24. 15 Temmuz 2019 tarihinde https://www.academia.edu/36248626/MUHAFAZAK\%-

C3\%82RLIK_\%C3\%9CZER\%C4\%B0NE adresinden erişilmiştir.

Heywood, A. (2017). Siyaset. (çev. B. B. Özipek vd.), İstanbul:Adres Yayınları. http://gulf2000.columbia.edu/, Erişim Tarihi: 25.04.2019.

http://gulf2000.columbia.edu/images/maps/Afghanistan_Religion_lg.-png,

Erişim 20 Temmuz 2019.

http://gulf2000.columbia.edu/images/maps/Iraq_Religions_lg.png Erişim 20 Temmuz 2019.

http://gulf2000.columbia.edu/images/maps/Lebanon_Religion_lg.png,

Erişim 20 Temmuz 2019

http://gulf2000.columbia.edu/images/maps/South_Sudan_Religion_lg.-png,

Erişim 21 Temmuz 2019.

http://gulf2000.columbia.edu/images/maps/SWA_Ethno-Religious_lg.-png, Erişim 21 Temmuz 2019.

http://gulf2000.columbia.edu/images/maps/Yemen_Ethno_Religious_lg.png, Erişim 21 Temmuz 2019.

http://www.tdk.gov.tr/index.php?option=com_gts\&arama=gts\&guid=TDK.GTS.5cc77aea95c768.58985128 , Erişim Tarihi: 25.04.2019.

http://www.tdk.gov.tr/index.php?option=com_gts\&kelime=ŞEHİR, Erişim Tarihi: 25.04.2019.

https://dictionary.cambridge.org/tr/s\%C3\%B6zl\%C3\%BCk/ingilizce/conservatism, Erişim Tarihi: 25.04.2019, Erişim Tarihi: 25.04.2019. 
https://www.britannica.com/topic/conservatism/General-characteristics, Erişim Tarihi: 25.04.2019.

https://www.conservationinstitute.org/what-is-urbanization/, Erişim Tarihi: 25.04.2019.

https://www.merriam-webster.com/dictionary/conservatism, Erişim Tarihi: 25.04.2019.

https://www.pewforum.org/2011/12/19/global-christianity-exec/, Erişim 21 Temmuz 2019.

https://www.sciencedaily.com/terms/urbanization.htm, Erişim Tarihi: 25.04.2019.

https://www.worldatlas.com/articles/christian-denominations-by-the-numbers.html, Erişim 21 Temmuz 2019.

İbn Haldun (t.y). Mukaddime. (çev. Z. K. Ugan), c.1, İstanbul:MEB. Yayınları. Izady, M. (2006). Atlas of the Islamic world and vicinity. Gulf 2000 Project, 2006, New York.

Keleş, R. (1980). Kent bilimleri terimler sözlüğüu. Ankara:TDK yayınları.

Mckinney, M. L. (2006). Urbanization as a major cause of biotic homogenization. Biological Conservation, 127(3), $247-260$.

Momen, M. (2019). An introduction to Shi'i Islam: The history and doctrines of twelver Shi'ism. 20 Temmuz 2019 tarihinde https://archive.org/details/IntroductionToShiiIslamByMoojanMomen/page/n157 adresinden erişilmiştir.

Okutan, M. Ç. (2013) Conservatism: Historical-phiosophical roots. Uluslararası İktisadi ve İdari İncelemeler Dergisi, 5(10), 127-134.

Pewform, The World's Muslims: Unity and Diversity, (2012). https://www.pewforum.org/2012/08/09/the-worlds-muslims-unityand-diversity-executive-summary/ Erişim 17 Temmuz 2019.

Sıcak, A. S. (2019). Kur'ân'da tasrîf olgusu ve Kur'ân kıssalarında Karye/Medîne kelimelerinin tasrîfi. Şarkiyat Dergisi 11(2), 734-762. https://doi.org/10.26791/sarkiat.581827

Swyngedouw E. (2004). Social power and the urbanization of water flows of power. Oxford University Press.

Swyngedouw, E. (1999). Modernity and hybridity: Nature, regeneracionismo, and the production of the Spanish waterscape:1890-1930. Annals of the Association of American Geographers, 89(3), 443-65.

Yılmaz, H. (2002). Türk Müslümanlığı dindarlık ve modernlik. İslamivat, 5(4), 63-82. 
Zengin, E. Ç. (2018). Kent ve kentlileşme sarmalında Türkiye. Kastamonu Üniversitesi İktisadi ve İdari Bilimler Fakültesi Dergisi, 20(1), 84-103.

\section{Kaynakça Bilgisi / Citation Information}

Aydın, A. ve Okşar, Y. (2019). Coğrafya-din ilişkisi; Kentlileşme, muhafazakârlık ve mezhep demografisi bağlamında doğu ve batı karşılaştırması. OPUS-Uluslararası Toplum Araştırmaları Dergisi, 14(20), 2012-2039. DOI: 10.26466/opus.600344 